Southern Methodist University

SMU Scholar

\title{
Reimagining the Wheel: Detention and Release of Non-State Actors under the Geneva Conventions
}

Chris Jenks

Southern Methodist University, Dedman School of Law

\section{Recommended Citation}

Chris Jenks, Reimagining the Wheel: Detention and Release of Non-State Actors under the Geneva Conventions in Detention of Non-State Actors Engaged in Hostilities (Gregory Rose and Bruce Oswald eds., Brill 2016)

This document is brought to you for free and open access by the Faculty Scholarship at SMU Scholar. It has been accepted for inclusion in Faculty Journal Articles and Book Chapters by an authorized administrator of SMU Scholar. For more information, please visit http://digitalrepository.smu.edu. 
CHAPTER 5

\title{
Reimagining the Wheel: Detention and Release of Non-State Actors under the Geneva Conventions
}

\author{
Chris Jenks* \\ 1 \\ Introduction
}

After more than a decade of sustained armed conflict, the international community continues to struggle with the issues posed by non-State actors participating in hostilities. ${ }^{1}$ Issues range from the micro, of if and when individuals may be targeted or detained, to the macro if not meta level of which legal regime to apply. While this myriad of issues is vexing, the issues non-State actors raise are neither as new, ${ }^{2}$ nor the applicable law as lacking, as is commonly believed. ${ }^{3}$

* Assistant Professor of Law, SMU Dedman School of Law. Prof Jenks formerly served as an officer and legal advisor in the United States Army, including a tour in Iraq advising on detention issues and another as the chief of the international law branch for the U.S. Army. He also worked as an attorney in the human rights and refugee section of the office of the legal advisor at the U.s. Department of State, including representing the United States during negotiations on humanitarian issues at the Third Committee of the United Nations General Assembly.

1 See The Copenhagen Process: Principles and Guidelines on the Handling of Detainees in International Military Operations, 19 October 2012, available at: <http://um.dk/en/ /media/UM/ English-site/Documents/Politics-and-diplomacy/Copenhangen\%20Process\%2oPrinciples $\% 20 a n d \% 20 G u i d e l i n e s . p d f>$ (Accessed 15 July 2015). The Copenhagen Process was a multi year effort led by Denmark, involving representatives from other countries, regional and international organizations, and civil society which developed principles designed to the guide the conduct of detention in international military operations.

2 For but one of many examples of previous conflicts involving non-State actors, see Thomas Pakenham, The Boer War (1991) (describing the and Boer War in South Africa, which featured belligerents who did not wear military uniforms, violations of the laws and customs of war by both sides, and, in terms of detention, one of the first concentration camps. British military interned the families of Boer Commandos).

3 See Memorandum for the President, 'Decision R E Application of the Geneva Convention on Prisoners of War to the Conflict with al Qaeda and the Taliban', 25 January 2002 (referring to the Geneva Convention's linitations on questioning prisoners of war as "obsolete" and other provisions as "quaint").

(c) KONINKLIJKE BRILL NV, LEIDEN, 2016 | DOI 10.1163/9789004310643_006

For use by the Author only | (C) 2016 Koninklijke Brill NV 
This chapter addresses one strand of the legal Gordian Knot - detention of non-State actors during armed conflict. It considers detention from a pragmatic approach, similar to Alexander's approach of cutting the knot. The proposition which follows is that the 1949 Geneva Conventions and Additional Protocols I and II, outmoded and seemingly inapplicable though they are in some respects, offer the most thorough, humane, realistic and readily available option for determining how to treat - and when to release - non-State actors detained during armed conflict.

Commencing by noting the inverse relationship between the prevalence of the types of armed conflict and the law applicable to those conflicts as a matter of law, the chapter proposes intermingling types and applications of the law of armed conflict. It acknowledges a series of de jure challenges to the application of the law governing international armed conflict (IAC) to situations of non-international armed conflict (NIAC) and also challenges to conflating treatment standards from Geneva Convention III governing prisoners of war with the civilian internment and release provisions of Geneva Convention IV applicable to civilians. Although much of the criticism directed at this approach is legally correct, it is practically unhelpful. ${ }^{4}$

Assuming a "successful" deconstruction of this proposal, critics must shift to positivism and a proposed alternative. Yet any such proposal would inevitably look a lot like some combination of Geneva Conventions III and IV. Moreover, there are considerable advantages, practically and in establishing legitimacy, of tethering a detention regime to the world's most ratified treaties which form the basis for how militaries around the world train to conduct detention operations. $^{5}$

From there, the chapter briefly discusses salient aspects of the detention regimes of both prisoners of war and civilian security threats and considers

4 For a similar reason, this chapter ignores the discussion of whether there are only two categories of individuals, prisoners of war or civilians, or whether there is some alternative category involving unprivileged belligerents. The majority view is that under Additional Protocol I's negative definition of civilian (a civilian is any person who doesn't belong to a POW qualifying category), the universe is binary, i.e. if someone is not a pow, then they are a civilian (Protocol Additional to the Geneva Conventions of 12 August 1949, and relating to the Protection of Victims of International Armed Conflicts (Additional Protocol I) of 8June 1977, 1125 UNTS 3 Article $5^{\circ}(1)$ ). The ICRC Commentary, however, notes that that "things are not always so straightforward" although an individual who did not qualify as a matter of law as a prisoner of war would still be treated as such (I CRC Commentary to Additional Protocol I art $45 \$ \S 1761$ and $173^{6}$ ). The debate over whether there are two or more categories of actors on the battlefield does not meaningfully advance the questions of detention, treatment and release of non-state actors.

5 See, among others, U.S. Army Regulation 190-98, 'Enemy Prisoners of War, Retained Personnel, Civilian Internees and Other Detainees', 1 October 1997.

\section{For use by the Author only | (C) 2016 Koninklijke Brill NV}


and critiques two recent United States approaches to detention review, one for detainees in Guantanamo Bay Cuba, the other for detainees in Parwan, Afghanistan. This chapter concludes that, while in some ways the United States has exceeded the international laws of armed conflict (LOAC) requirements for detention reviews, in other significant ways the United States continues to fall short. Theses successes and failures suggest a broadly applicable prescription for the review of non-State actor detention. Ultimately a more direct link is proposed between detention review policy and the practice Geneva Convention IV envisioned.

\section{$2 \quad$ Authority to Detain in Armed Conflict: Quantum of Law vs Prevalence of Conflict}

The LOAC does not provide positive authority to detain. ${ }^{6}$ Indeed, the LOAC does not, in and of itself, provide authority for conduct of any kind. Rather the LOAC is a set of State-made international rules designed to humanize armed conflict to the extent possible by limiting its effects. That said, detention is considered within the nature of, ${ }^{7}$ or inherent to, ${ }^{8}$ armed conflict and the LOAC reflects that for both IAC and NIAC.

6 See David Tuck, Detention by Armed Groups: Overcoming Challenges to Humanitarian Action, 93 International Review of the Red Cross 759 (2011) at 765 (stating that "by one reading, humanitarian law regulates the treatment and conditions of deprivation of liberty" in armed conflict, "but does not establish its legality. In the alternative, international humanitarian law ( $\mathrm{IHL}$ ) can be understood implicitly to confer an authority to deprive people of liberty upon parties to NIAC. Indeed, reference to 'persons, hors de combat by...detention' and 'regularly constituted courts' in Common Article 3 , and to persons 'interned' in Additional Protocol II Articles 5 and 6, are superfluous if not understood to be accompanied by an authority to detain or intern respectively.").

7 The u.s. Supreme Court confronted the issue of authority to detain in Hamdi v. Rumsfeld, a case brought by a U.S. citizen detained during hostilities in Afghanistan. While acknowledging that the domestic law authorizing "all necessary and appropriate force" did not refer to detention, the Court stated that "detention to prevent a combatant's return to the battlefield is a fundamental incident of waging war" a proposition on which the Court claimed "universal agreement and practice." Hamdiv. Rumsfeld, 542 U.S. 507 (2004) at 519 See Ex parte Quirin, 317 U.S. 1 (1942) at $3^{1}$ (stating that "[l]awful combatants are subject to capture and detention as prisoners of war by opposing military forces. Unlawful combatants are likewise subject to capture and detention, but in addition they are subject to trial and punishment by military tribunals for acts which render their belligerency unlawful").

8 Jelena Pejic, The Protective Scope of Common Article 3: More Than Meets the Eye, 93 International Review of the Red Cross 189 (2011) at 207 (stating that "[i]n the ICRC's view, both treaty and customary $\mathrm{IHL}$ contain an inherent power to intern....").

\section{For use by the Author only | (C) 2016 Koninklijke Brill NV}


In IAC, armed conflict between two or more high contracting parties, ${ }^{9}$ Geneva Convention III is devoted to prisoners of war, i.e. members of one armed force detained by the other, ${ }^{10}$ while Geneva Convention IV details regulations for the treatment of internees, civilians detained as security threats. ${ }^{11}$ Additional Protocol I to the Geneva Conventions also contains a list of fundamental guarantees on the treatment of persons in the power of a party to a conflict ${ }^{12}$ recognized as customary international law. ${ }^{13}$

In NIACs, Common Article 3 applies, although contained in the otherwise IAC 1949 Geneva Conventions. Common Article 3 refers to members of the armed forces placed in detention in its categorization of "persons taking no active part in hostilities." ${ }^{\text {14 }}$ Additional Protocol II to the 1949 Geneva Conventions, which provides the bulk of treaty-based NIAC law, contains an article on "persons whose liberty has been restricted"15 and another on "penal prosecutions."16 Yet, despite the titles of its articles, Additional Protocol II "does not give details of how [detention] is to be organized."17

9 See Article 2 common to all four of the 1949 Geneva Conventions, which states that conventions "shall apply to all cases of declared war or of any other armed conflict which may arise between two or more of the High Contracting Parties, even if the state of war is not recognized by one of them."

10 Geneva Convention Relative to the Treatment of Prisoners of War (Geneva Convention 111), of 12 August 1949, 75 UNTS 135.

11 Geneva Convention Relative to the Protection of Civilian Persons in Time of War (Geneva Convention IV), of 12 August 1949, 75 UNTS 287.

12 Additional Protocol I Article 75.

13 The vast majority of the world, some 173 States, are party to Additional Protocol I. See <http://www.icrc.org/applic/ihl/ihl.nsf/States.xsp?xp_viewStates=XPages_NORM StatesParties\&xp_treatySelected $=\mathrm{D}_{9} \mathrm{E}_{6 \mathrm{~B} 6264} \mathrm{D}_{7723} \mathrm{C}_{3} \mathrm{C}_{125} 6_{3} \mathrm{CDoon}_{2} \mathrm{DCCE}_{4}>$ (Accessed 15 July 2015); But for those States that aren't, portions of Additional Protocol I, including Article 75, are binding as customary international law, a point even the United States acknowledges. White House, Fact Sheet: 'New Actions on Guantanamo and Detainee Policy', 7 March 2011, available at: <http://www.whitehouse.gov/the-press-office/2011/03/07/ fact-sheet-new-actions-guant-namo-and-detainee-policy> (Accessed 15 July 2015).

14 Geneva Convention III Article 3; See Hamdan v. Rumsfeld, 548 U.s. 557 (2006).

15 Protocol Additional to the Geneva Conventions of 12 August 1949, and relating to the Protection of Victims of Non-International Armed Conflicts (Additional Protocol II) of 8 June 1977, 1225 UnTs 609 Article 5; Pejic, supra note 8.

16 Additional Protocol II Article 6.

17 Jelena Pejic, Procedural Principles and Safeguards for Internment/Administrative Detention in Armed Conflict and Other Situations of Violence, 87 International Review of the Red Cross 377 (2005).

\section{For use by the Author only | (c) 2016 Koninklijke Brill NV}


While there are references to detention in the bodies of law governing both classifications of conflict, there is an unhelpfully inverse nature in the amount of law available and applicable between those classifications. The vast majority of the LOAC on detention, notably the 1949 Geneva Conventions and Additional Protocol I, is triggered only by IAC. An armed conflict involving non-State actors, even disparately located in several countries, cannot legally constitute an IAC. In the aftermath of World War II, NIACs are far more prevalent but there is far less law, both available and applicable to detention in NIAC. ${ }^{18}$ The larger body of IAC law on detention is legally inoperative and inapplicable.

The answer to IAC detention questions is necessarily grounded in policy not law. Professor Ryan Goodman has articulated a three-part rationale for a policy of applying IAC law to NIACs against non-State actors like al Qaeda.

The first is a reactive reason; simply put, many commentators and practitioners have applied the law of international armed conflict to the conflict with al Qaeda by analogy. It's a prevalent practice that's used, for example, in debates about whether or not we can hold fighters until the cessation of hostilities and with or without access to an attorney. The analog or the referent in those discussions is often international armed conflict. And if that's a prevalent mode of discourse or argument, then we at least need to evaluate those kinds of claims.

A second reason is an affirmative one. On my view, it's valid to use the law of international armed conflict as an analogy. In fact, if we have to think of an analogy, it's the closest fit or closest approximation-especially the Fourth Geneva Convention for questions of who may be detained and what types of activities on the part of civilians are subject to detention. That is, the rules contained in the Civilians Convention, are the closest analog that we have and therefore the best reference point for trying to approximate what the law of armed conflict should look like or will look like when it applies in a non-international scenario like the conflict with al Qaeda.

The third reason is the strongest, and it's an affirmative argument not just by way of analogy. The argument here is that the law in international armed conflict establishes an outer boundary of permissive action. The idea is fairly simple, which is that the law of armed conflict uniformly involves more exacting, more restrictive obligations on parties in international armed conflict than in non-international armed conflict. We could even state this point as a

18 For example, according to the North Atlantic Treaty Organization, in 2000 there were 25 armed conflicts around the world. <http://nato.gov.si/eng/topic/threats-to-security/ statistics/> Of those, only one, the conflict between India and Pakistan, was of an international nature. See also Armed Conflict Database, <http://acd.iiss.org> (Accessed 15 July 2015).

For use by the Author only | (C 2016 Koninklijke Brill NV 
maxim: if states have authority to engage in particular practices in an international armed conflict, they a fortiori possess the authority to undertake the same practices in non-international armed conflict, or simply put, whatever is permitted in international armed conflict is permitted in non-international armed conflict. Therefore, if the law of armed conflict permits a state to detain civilians in international armed conflict, the law of armed conflict surely permits states to detain civilians in a non-international armed conflict.

The same logic does not apply to prohibitions or proscriptive rules: it does not follow that if the law of armed conflict forbids states from engaging in-a practice in international armed conflict that the law would also forbid states from engaging in that practice in non-international armed conflict. ${ }^{19}$

Applying Goodman's rationale allows for the discussion of prisoner of war (POW) and civilian detention, first generally, then as applied to non-State actors. Arguing that Goodman is wrong, that Geneva Conventions III and IV do not, as a matter of law, apply to non-state actors like al Qaeda and the Taliban is correct, and in more than one way. But the result is a Pyrrhic victory from which one has nothing to show. This technical approach, while legally sound, is deconstructionist. It removes a large portion of the internationally recognized and accepted provisions for regulating detention associated with armed conflict. At some point, even the deconstructionist must propose an alternative. And any alternative will inevitably resemble that which is already extant in the LOAC.

\section{3}

\section{Geneva Convention IxI - Prisoners of War}

On a broader or strategic level, the capture of members of the opposing force in armed conflict is one of numerous measures employed as part of an overall effort to bring the enemy to submission. At a narrower, tactical or operational level, by capturing and incapacitating members of the opposing force, the capturing force ensures it will not face those same members in future engagements.

Capture of a member of the enemy force is based on his/her status as such, not on an individualized assessment of the threat posed. The LOAC presumes that belligerent operatives "are part of the military potential of the enemy and it is therefore always lawful to attack [and thus to capture] them for the

19 Ryan Goodman, The Second Annual Solf-Warren Lecture in International and Operational Law, 201 Milton Law Review 237 (2009).

For use by the Author only | (C) 2016 Koninklijke Brill NV 
purpose of weakening that potential." 20 As the ICRC acknowledges, "[p]risoners of war may be interned ... for no individual reason. The purpose of this internment is not to punish them, but only to hinder their direct participation in hostilities and/or to protect them." 21

Nonetheless, even if the full panoply of IAC law did apply generally to NIACs, the specific provisions of Geneva Convention II I would still not apply to most non-State actors because they don't make up the military of a party to the conflict or comply with the conditions for free standing militias or volunteer corps. ${ }^{22}$ That's not to say that the Geneva Conventions make no provision for non-State actors, they do. Members of militias or volunteer corps who make up the armed forces of a party to the conflict qualify for prisoner of war status and treatment. ${ }^{23}$ Even militias or volunteer corps which don't directly comprise the armed forces of a party may qualify for pow status and treatment. ${ }^{24}$ Interestingly, there is no geographic limitation; the provisions of Geneva Convention III apply to militias operating "in or outside their territory."25

20 Marco Sassóli \& Laura Olson, The Relationship Between International Humanitarian and Human Rights Law Where it Matters: Admissible Killing and Internment of Fighters in NonInternational Armed Conflicts, 90 International Review of the Red Cross 599 (2008) at 606.

21 Marco Sassòli, et al., How does Law Protect in War? Cases, Documents and Teaching Materials on Contemporary Practice in International Humanitarian Law (2011) at 10, available at: <http://www.icrc.org/eng/assets/files/publications/icrc-0739-part-i.pdf>, (Accessed 15 July 2015).

22 Following the $9 / \mathrm{Il}$ attacks, the United States considered the status under international humanitarian law of both the Taliban, which constituted the government of Afghanistan at the time, and al Qaeda, which based its terrorist organization in Afghanistan with Taliban consent. White House, 'Humane Treatment of Taliban and al Qaeda Detainees', 7 February 2002, available at: <http://www.pegc.us/archive/White_House/bush_memo_20020207_ed .pdf> (Accessed 15 July 2015); Memorandum Opinion for the Counsel to the President, 'Status of Taliban Forces Under Article 4 of the Third Geneva Convention of 1949', 7 February 2002, available at: <http://fas.org/irp/agency/doj/olc/taliban.pdf> (Accessed 15 July 2015).

23 Geneva Convention III Article 4.

24 In order to qualify for Pow status, members of other militias and volunteer corps which do not form part of the armed forces of a party to the conflict must fulfill the following conditions:

That of being commanded by a person responsible for his subordinates; That of having a fixed distinctive sign recognizable at a distance; That of carrying arms openly; That of conducting their operations in accordance with the laws and customs of war Geneva Convention III Article 4.

For use by the Author only | (C) 2016 Koninklijke Brill NV 
Consider the armed conflict engaging the United States in Afghanistan following the September 11 attacks: At the outset the conflict was an IAC, a war between two high contracting parties to the Geneva Conventions, the United States and Afghanistan. Status as an IAC triggered at least the potential for the application of Geneva Convention III. Although members of al Qaeda could potentially have qualified for Pow status and treatment as members of a militia, there was not a credible argument that al Qaeda complied with the prerequisite for Pow status, a four part test for a command structure, fixed distinctive sign recognizable at a distance, carrying of their arms openly and following the LOAC.

An assessment of the Taliban, which represented the government of Afghanistan, is more difficult. In denying the Taliban Pow status, the us claimed that even if the Taliban constituted the armed forces of Afghanistan they would still have needed to meet the four-part test. This argument is not supported by a plain reading of the text of Geneva Convention II I and was criticized; ${ }^{26}$ yet the argument finds indirect support from the ICRC and is persuasive at a normative level. In terms of ICRC support, the commentary to Geneva Convention III, in explaining another category of persons who qualify for POW status, refers to the attributes of armed forces as "they wear uniform, they have an organized hierarchy and they know and respect the laws and customs of war."27 More broadly, if the armed forces of a party to the conflict are not required to met the four part test, a perverse result follows: members of a regular armed force would be held to a lesser standard than those applicable to non regulars militia and volunteer forces. ${ }^{28}$

26 See Silvia Borelli, Casting Light on the Legal Black Hole: International Law and Detentions Abroad in the "War on Terror" 87 International Review of the Red Cross 39 (2005).

27 International Committee of the Red Cross, Commentary on the Geneva Convention III Relative to the Treatment of Prisoners of War (1960) at 63. And the 1949 Geneva Conventions listing of members of the armed forces as qualifying for Pow status derives from the 1899 Hague Convention. And under that Convention, to qualify for Pow status an individual must be member of a State's armed forces but also meet the four-part test. Convention (II) with Respect to the Laws and Customs of War on Land of 18 October 1907, 36 Stat. 2277, T.S. No. 403 , Article. 1 .

28 See Status of Taliban Forces, supra note 22 at 5 . As the U.S. Department of Justice indicated, " $t$ ]here is no evidence that any of the GPW's drafters or ratifiers believed that members of the regular armed forces ought to be governed by lower standards in their conduct of warfare than those applicable to militia and volunteer forces." (emphasis in original) The idea that a regular armed force could exist but not have a chain of command, wear a uniform/insignia, carry their arms openly or follow the LOAC is a non sequitur.

\section{For use by the Author only | (C) 2016 Koninklijke Brill NV}


Regardless of how one answers the question of whether the Taliban and al Qaeda were entitled to Pow treatment, there is a more practical concern with what the application of Geneva Convention II doesn't do. Although it yields a robust guide on pow treatment conditions, ranging from quarters, food, clothes, hygiene and medical attention, to religious, intellectual and physical activities, it doesn't provide much in the way of guidance on release. That's not a criticism of the Convention but a statement of its inherent limitations given that the detention regime is status-based. ${ }^{29}$ It provides simply that its protections "shall apply...from the time [a qualifying person] fall[s] into the power of the enemy and until their final release and repatriation." ${ }^{30}$ In terms of timing of release, a subsequent section of Geneva Convention III, although comprising only two articles, requires that "prisoners of war shall be released and repatriated without delay after the cessation of hostilities." ${ }^{31}$

At the time of the drafting of Geneva Convention III in the aftermath of World War II, defining the cessation of hostilities was relatively straightforward. During WwII, the various Axis forces submitted and signed instruments of surrender. Therefore, Geneva Convention III presupposes status as an immutable quality; e.g. during the war in the Falklands, if the British detained a uniformed member of the Argentine Army, that individual's status remained constant as a member of the armed forces of a party to the conflict. Thus, Geneva Convention III recognizes broad, status-based detention and provides considerable guidance on treatment, but is of limited use in terms of release. ${ }^{32}$

Furthermore, the conclusion of NIACs involving non-State actors who increasingly operate from more than one state and are aligned to varying degrees with other organized armed groups is not so straight forward. ${ }^{33}$ Returning to

29 That of course presupposes status as an immutable quality. If during the war in the Falklands, the British detain a uniformed member of the Argentine Army, that individual's status remains constant, a member of the armed forces of a party to the conflict. And under Geneva Convention III "prisoner of war many in no circumstances renounce in part or in entirety the rights secured to them" under the Convention. Geneva Convention III Article 7 .

30 Id Article 5.

31 Id Article 118.

32 While outside the scope of this chapter, another major objection States have to affording non-State actors Pow status is affording them combatant immunity. See Geoff Corn, Thinking the Unthinkable: Has the Time Come to Offer Combatant Immunity to Non-State Actors? 22 Stanford Law \& Policy Review 1 (2011).

33 Consider the dynamic relationship between al Qaeda groups, in Pakistan and Afghanistan but previously in Iraq and in the Arabian peninsula and al Qaeda in the Magreb. See

For use by the Author only | (C) 2016 Koninklijke Brill NV 
the Falklands example, there are no gradients in being a member of the Argentine armed forces, either one is or is not. But there are degrees of membership in groups like al Qaeda. Flowing from that difficulty, the current conflict in Afghanistan is approaching its 14th year first as a short-lived IAC and predominantly as a long-term NIAC.

An alternative to the application of Geneva Convention III on POWs is the application of Geneva Convention IV on civilians. One difficulty, from a State's perspective, in applying Geneva Convention IV to non-State actors, however, is that the conduct-based threshold allowing for detention under Geneva Convention IV is higher than the status-based threshold for detaining a member of the armed forces. A possible solution is to utilize status as a basis for detention of individuals who would otherwise be considered civilians subject only to conduct based detention.

However, allowing status-based detention of non-State actors could result in over extension of detentions, with more individuals being detained than would be the case if the detaining entity had to identify specific threat-based actions as warranting detention. Nevertheless, aspects of Geneva Convention IV grafted on could serve as an implicit check on how such detention would occur. Were a military to believe that an individual was a member of al Qaeda and to order his detention, and it turned out the individual was not a member as such or conducting any activities at al Qaeda's behest, the individual would be released no later than upon the first six month review (discussed infra). While six months of unnecessary detention is problematic, at least it's a finite problem.

Moreover, in a counter- insurgency environment, status-based detention of non-State actors would in some ways be self-regulating. A military commander who detains too many people who don't in fact pose a security threat will undermine his or her own relationship with the local populace and their perceptions of legitimacy and, as the U.s. Army's Counterinsurgency Field Manual states, "lose moral legitimacy, lose the war." ${ }^{4}$

There is inevitably going to be over or under extension in any detention system and, indeed, in any legal system it's a question of which, and who should

MSNBC, Letter to al-Zarqai from al-Zawahri, 11 October 2005, available at: <http://www .nbcnews.com/id/9666242/ns/world_news-terrorism/t/letter-al-zarqawi-al-zawahri/\#. UhFgDGRoyA1> (Accessed ${ }_{15}$ July 2015) (describing communication between the Head of al Qaeda in Pakistan and the head of al Qaeda in Iraq); Helen Collis and Hayley Peterson, Head of al Qaeda in Pakistan Ayman al-Zawahri communicated with Nasser al-Wuhayshi, the head of al Qaeda in the Arabian Peninsula, Daily Mail 4 August 2013 (describing communication between the head of al Qaeda in Pakistan and his counterpart in Yemen). U.s. Army Field Manual 3-24, 'Counterinsurgency', December 2006.

For use by the Author only / (C) 2016 Koninklijke Brill NV 
incur the risks or pay the costs. Weighing the interests of members of an armed force who comply with the LOAC, the civilian population, and non-State actors, it is proposed here that non-State actors should bear the risk of over extension in a status-based detention regime. That risk is of a finite deprivation of liberty, while not desirable, is certainly "less bad" than the current status quo, i.e. indefinite deprivation of liberty ${ }^{35}$ and it comes the more robust review process of Geneva Convention Iv.

4

\section{Geneva Convention IV - Detention of Civilians}

In contrast to to the status-based pow detention regime under Geneva Convention III, the detention of civilians regime under Geneva Convention IV is conduct- based. Article 78 recognizes that "[i]f an occupying power considers it necessary, for imperative reasons of security" then it may intern civilians. ${ }^{36}$

Because such internment or detention is conduct-based, there is a greater temporal limitation on its duration than the nebulous "end of hostilities" of status-based pow detention. The initial decision to detain a civilian for imperative security reasons is subject to an initial review "as soon as possible by an appropriate court or administrative board" designated by the detaining power. ${ }^{37}$ Following that initial review, periodic reviews are mandatory and automatic and conducted at least twice a year. Significantly, those reviews are conducted "with a view to favorably amending the initial decision if circumstances permit."38

Placing the risk on the State force would, and arguably has already, lead to more nonState actors being killed rather than detained. See Karen DeYoung \& Joby Warrick, Under Obama, More Targeted Killings Than Captures in Counterterrorism Efforts, Washington Post, 14 February 2010, available at: <http://www.washingtonpost.com/wp-dyn/content/ article/2010/02/13/AR2010021303748.html> (Accessed 15July 2015).

${ }_{3} 6$ Geneva Convention Iv Article 78. Elsewhere in the Fourth Geneva Convention the predicate for internment is if it is "absolutely necessary." See Article 42 The difference between the two articles is that unlike Article 42, Article 78 "relates to people who have not been guilty of any infringement of the penal provisions enacted by the Occupying Power, but that Power may, for reasons of its own, consider them dangerous to its security and is consequently entitled to restrict their freedom of action." Commentary to Article 78 . Nonetheless, the commentary states that internment must "observe the stipulations of Article $43 . "$ Id.

37 Geneva Convention IV Article 43.

38 Oscar Uhler, et al., Commentary, 'Geneva Convention Iv Relative to the Protection of Civilian Persons in Time of War' at 260-262.

For use by the Author only | (C) 2016 Koninklijke Brill NV 
Judicial review of detention is not required under the LOAC, an administrative board suffices. ${ }^{39}$ However, "where the decision is an administrative one, it must be made not by one official but by an administrative board offering the necessary guarantees of independence and impartiality" 40 and the board must be conducted with "absolute objectivity and impartiality." ${ }^{11}$ Here the approach of the United States, historically and in both Afghanistan and Guantanamo, is instructive.

\subsection{United States Approaches}

For the United States, detaining individuals during armed conflict and treating them favourably under the terms of a prisoner of war status for which they do not qualify as a matter of law is nothing new. During the Korean conflict, the United States did not recognize the legitimacy of Chinese intervention. Regardless of the accuracy of that view, the consequence was that the United States did not believe that members of the Chinese Army qualified as pows as a matter of law, but the United States treated them as such as a matter of policy.

Similarly, during the Vietnam war, the United States, along with its allies, ${ }^{42}$ joined South Vietnam in fighting an array of enemies associated with North Vietnam. Some, like the North Vietnamese Army, were clearly entitled to Pow status and treatment. But others forces, notably the Viet Cong, did not qualify as Pows. The United States held Article 5 tribunals $^{43}$ on captured Viet Cong

Geneva Convention Iv Article 42.

Uhler, Commentary, supra note 38 at 260 .

Id.

Notably Australia, New Zealand, the Republic of Korea, and Thailand.

Under Geneva Convention III, "[s]hould any doubt arise as to whether persons having committed a belligerent act and having fallen into the hands of the enemy belong to any of the categories [qualifying as Pows], such persons shall enjoy the protection of [the pow Convention] until such time as their status has been determined by a competent tribunal." Geneva Convention II Article 5. The Convention does not specily the conduct of such a tribunal. In Vietnam, the U.s conduct of Article 5 tribunals was little more than bringing the captured individual before an U.S. Army officer who inquired about the circurnstances of capture and afforded the individual the opportunity to provide input. See also Geoffrey Corn, Eric Talbot Jensen \& Sean Watts, Understanding the Distinct Function of the Combatant Status Rexiew Tribunals: A Response to Blocher, 116 Yale Law Journal pocket Part 327 (2007), (describing how the U.s. identified as a matter of policy, groups qualifying for Pow status, including Viet Cong Main Forces, Viet Cong Local Forces, North Vietnamese Army Units, and Organized Forces of Irregular Guerillas and Self-Defense Forces who had not engaged in terrorism, sabotage or spying. U.s. Military Assistance Command, Vietnam, Directive No. 381-46, 'Military Intelligence: Combined Screening of Detainees' 27 December 1967 , reprinted in Howard Levie, Documents on Prisoners of War, 60 International Law Studies 748 (1979).

\section{For use by the Author only | (C) 2016 Koninklijke Brill NV}


and determined they were not pows. Nonetheless, the United States then treated the Viet Cong as Pows, and housed them in camps literally adjacent to the pow camps for captured North Vietnam armed forces.

The United States currently adopts different approaches to detention review depending on whether the individual is being detained at Guantanamo or Afghanistan. These approaches are "informed by the law of war." In some ways, particularly in Afghanistan, the mechanisms provide more rights and process than the LOAC requires (although the Afghanistan approach has unfortunately proven more theory than practice given the transfer of detention operations to the Government of Afghanistan). In other ways, and particularly in Guantanamo, the detention review process significantly departs from the LOAC with the unfortunate result that, despite having over time significantly raised the bar in terms of detainee rights and process, the overall perception of the legitimacy of United States detention policy remains poor. Micro improvements, implemented slowly, do little to alter the negative perception. Instead, what is needed, and would be more defensible and perceived as more legitimate, is to increase the nexus between us detention policy and the LOAC.

\subsection{Afghanistan}

In December 2011, the United States enacted the National Defense Authorization Act (NDAA) for 2012. ${ }^{44}$ As part of the NDAA, the United States Congress directed that the Department of Defense (DoD) develop procedures for determining the status of persons held in long term detention under the law of war. ${ }^{45}$ In Section 1024 of the NDAA, the U.S. Congress mandated that the:

(1) A military judge shall preside at proceedings for the determination of status of an unprivileged enemy belligerent; and

(2) An unprivileged enemy belligerent may, at the election of the belligerent, be represented by military counsel at proceedings for the determination of status of the belligerent. ${ }^{46}$

The use of military judge and counse ${ }^{47}$ represent a significant increase in rights and processes afforded detainees and exceed the LOAC requirements.

44 Public Law 112-81. While it sounds timely to pass a law for 2012 in December 2011, the authorization act was for the fiscal year the Department of Defense operates on, which runs ${ }_{1}$ October $-3^{0}$ September. So the authorization act was enacted some three months into the year to which it applied.

45 Id at s 1024.

46 Id at s 1024 (b).

47 Note that the requirement is for military counsel, not military defense counsel. The difference being all members of the services Judge Advocate Generals' Corps are military

For use by the Author only | (C) 2016 Koninklijke Brill NV 
The DoD submitted a "Report on the Procedures for Unprivileged Enemy Belligerent Status Determinations" in March, 2012. ${ }^{48}$

It noted that it "is not required, and does not intend, to apply the Section 1024 procedures to any detainee currently detained at Guantanamo, since habeas corpus review is available to those detainees in federal court." ${ }^{49}$ Instead, " $[t]$ he Department of Defense intends to apply the status determination procedures in the case of any detainee not currently detained at Guantanamo whom the Department of Defense has determined....to be an unprivileged enemy belligerent." ${ }^{\text {"50 }}$ At that time, it was known that DoD was detaining unprivileged enemy belligerents at Guantanamo and the Detention Facility in Parwan, Afghanistan. ${ }^{51}$ Thus, the provisions, when issued in March 2012, applied to the roughly 3,000 unprivileged enemy belligerents the United States was detaining in Parwan, Afghanistan. ${ }^{52}$

In addition to excluding Guantanamo, the March 2012 report also stated that " $[t]$ he Department of Defense does not intend to apply the [2012 NDAA provisions] in the case of any detainees who are transferred to the custody and control of the Government of Afghanistan pursuant to the Memorandum

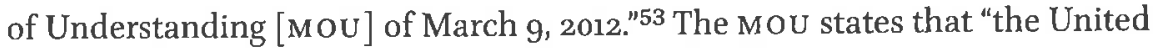

counsel. A small percentage of that total serve specifically as defense counsel. So a detainee may elect to be represented by a military lawyer, or Judge Advocate (a huge leap from the non lawyer personal representative) but that lawyer is not required to be a defense counsel.

48 Department of Defense, 'Report on the Procedures for Unprivileged Enemy Belligerent Status Determinations', March 2012.

49 Id.

$50 \quad$ Id.

$5^{1}$ The specific wording is that the "Department of Defense currently detains unprivileged enemy belligerents pursuant to the AUMF [Authorization to Use Military Force], as informed by the laws of war" at Guantanamo and Parwan. The qualifier "pursuant to the" raises the question about whether $\mathrm{DoD}$ is detaining individuals elsewhere pursuant to something besides the AUMF. Additionally, the report could, but does not, say "only" at Guantanamo and Parwan.

52 The Department of Defense Claims that of those detained at Parwan "the vast majority are Afghan nationals."

53 Department of Defense, supra note 48. See Memorandum of Understanding between The Islamic Republic of Afghanistan and the United States of America 'On Transfer of U.S. Detention Facilities in Afghan Territory to Afghanistan', 9 March 2012, available at: <http:// mfa.gov.af/en/news/7671> (Accessed 15 July 2015). And the MOU refers to detention processes "consistent" with Additional Protocol II. And while Additional Protocol II is the LOAC applicable to NIAC, as previously discussed Additional Protocol II provides minimal guidance on the detention treatment and none on release.

For use by the Author only / (C 2016 Koninklijke Brill NV 
States Commander at the [Detention Facility] is to retain responsibility for the detainees held by the United States at the DFIP under the Law of Armed Conflict during the processing and transfer period, which is not to last more than six months. ${ }^{54}$ At least one commentator has suggested that the provision allows the United States "the option of retaining control of each freshly detained person for a maximum of six months before transferring him to the Afghan authorities." 55 Pursuant to the MOU, the United States has transferred over Afghan nationals at Parwan, who, according to the Department of Defense, comprise the "vast majority" of the detainees. ${ }^{56}$ The United States transfer of Parwan Detention Facility was not finalized until the spring of 2013, later than anticipated. ${ }^{57}$

That left roughly 67 non-Afghan detainees under United States control for whom the NDAA provisions would apply. ${ }^{58}$ Under the NDAA, the United States will review the basis for detention "as soon as practicable but not later than 18 months after the detainee is captured by, or transferred to the custody and control of, the Department of Defense." 59

In addition to utilizing a military judge to conduct the detention review and providing the detainee with no cost military legal representation, other notable provisions of the DoD plan are that:

- A Judge Advocate will serve as the recorder and shall be sworn.

- A written record of the proceedings will be made and preserved as part of the detainee's record.

54 See Memorandum of Understanding supra note 53 Article 6C.

55 Kate Clark, Terms of Internment, Foreign Policy, 1 June 2012, available at: <http://afpak .foreignpolicy.com/posts/2012/o6/o1/the_terms_of_internment> (Accessed 15 July 2015). Ms Clark claimed that "when asked about [the possibility of the us retaining control for new detainees for up to six months], the U.s. embassy spokesman would only say: "We have nothing further for you on this topic at this time."

56 Department of Defense supra note 48.

57 Associated Press, us Military Gives Control of its Last Detention Center to Afghans, 25 March 2013, available at: <http://www.foxnews.com/politics/2013/03/25/us-military -to-hand-over-detention-facility-to-afghan-government/> (Accessed 15 July 2015).

58 Kevin Sieff, In Afghanistan, a Second Guantanamo, Washington Post, 4 August 2013, available at: <http://www.washingtonpost.com/world/in-afghanistan-a-second-guantanamo/2013/08/04/e33e8658-f53e-11e2-8Ifa-8e83b3864c36_print.html> (Accessed 15 July 2015). Seiff contends the majority of the non Afghan detainees are Pakistani and that essentially Afghanistan is allowing the U.s. to detain non Afghans in exchange for having handed over the Afghan detainees. Department of Defense supra note 48.

For use by the Author only | (C) 2016 Koninklijke Brill NV 
- Proceedings will be open to the extent practicable, except for deliberations and testimony or other matters that would compromise national security, operational security, or law enforcement interests if held in the open. The military judge may enter appropriate protective orders regarding classified or other sensitive information, as necessary.

- At the beginning of the review proceedings, the detainee will be advised, in writing and orally in a language the detainee understands, of the purpose of the hearing, his or her opportunity to present information, and the consequences of the military judge's determination.

- The detainee will be allowed to attend all open sessions, subject to operational or security concerns, or law enforcement interests, and will be provided with an interpreter if necessary.

- The recorder and the detainee will be allowed to call witnesses if reasonably available and considered by the military judge to have relevant testimony to offer. Each will be allowed to question witnesses called by the other or the military judge, subject to operational or national security concerns.

- The detainee will be allowed to testify or otherwise address the military judge through a written or oral statement.

- The detainee will not be compelled to testify or otherwise address the military judge.

- The recorder and the detainee will be allowed to present documentary information relevant to the determination of whether the detainee is a covered person as defined in subsection (b) of Section 1021 of the Act.

- Determinations pursuant to these procedures will not rely upon any information obtained by torture or through cruel, inhuman, or degrading treatment.

- The government has the burden of demonstrating by a preponderance of the evidence that the detainee is a covered person ${ }^{60}$ as defined in subsection (b) of Section 1021 of the Act.

- A written report of the military judge's determination will be completed in each case, including a summary of all information considered, as soon as practicable following the proceeding. The military judge's determination will be preserved as part of the detainee's record.

6o Under $\mathrm{s} 1021$ (b) "A covered person under this section is any person as follows: (1) A person who planned, authorized, committed, or aided the terrorist attacks that occurred on September 11, 2001, or harbored those responsible for those attacks.

(2) A person who was a part of or substantially supported al-Qaeda, the Taliban, or associated forces that are engaged in hostilities against the United States or its coalition partners, including any person who has committed a belligerent act or has directly supported such hostilities in aid of such enemy forces."

For use by the Author only | (C) 2016 Koninklijke Brill NV 
- The detainee will receive notice of the military judge's determination, in writing and orally in a language the detainee understands, as soon as practicable but not later than 72 hours after the written report of the military judge's determination is completed. ${ }^{61}$

These procedures mark a significant advancement in detainee rights and the process in determining the status of detained persons. In a sense, the NDAA provides for the most robust Article $\mathrm{V}$ tribunal imaginable, complete with judge and lawyers, but it does so at a point so long after detention occurs. It seems a case of "too much, too late". What is not clear is, if a detainee is found to be a "covered person", how often and by what process will his/her continued detention be reviewed? Indeed some are calling the United States new detention model in Afghanistan "a second Guantanamo".

\subsection{Guantanamo}

While the United States has refined the initial status determination in Afghanistan, the United States continues to struggle with how to do so for those detained at Guantanamo. In March, 2011, United States President Barack Obama issued Executive Order 13567, titled "Periodic Review of Individuals Detained at Guantanamo Bay Naval Station Pursuant to the Authorization for Use of Military Force." 62 Yet not until the NDAA requirement that DoD submit a report "setting forth the procedures determining the status" did the functional reality of the President's order emerge. ${ }^{63}$ In May 2012, the DoD issued 23 pages of "Implementing Guidelines for Periodic Review of Detainees Held at Guantanamo Bay per Executive Order 13567 " and established a website for the "Periodic Review Secretariat."64

61 Department of Defense, supra note 48.

62 Executive Order 13567 - Periodic Review of Individuals Detained at Guantanamo Bay Naval Station Pursuant to the Authorization for Use of Military Force', 10 March 2011, available at: <http://www.gpo.gov/fdsys/pkg/FR-2011-03-10/pdf/2011-5728.pdf> (Accessed 15 July 2015).

63 Public Law 112-81, s 1023 .

64 Directive-Type Memorandum (DTM) 12-005, 'Implementing Guidelines for Periodic Review of Detainees Held at Guantanamo Bay per Executive Order $135^{6} 7^{\prime} 9$ May 2012, available at: <http://www.prs.mil/Portals/6o/Documents/DTM-12-005_Implementing_Guide lines_for_Periodic_Review_of_Detainees_Held_at.pdf> (Accessed 15July 2015).

More than a year lapsed until July 2013 when the Department of Defense emailed counsel of the detainees at Guantanamo, purportedly after 1opm on a Friday night, that the periodic reviews would be starting, though exactly when remains unclear. Carol Rosenberg, Pentagon prepares review panels for 71 Guantánamo detainees, Miami Herald,

\section{For use by the Author only | (C) 2016 Koninklijke Brill NV}


The review process that emerged does not address the legality of any detainee's law of war detention, ${ }^{65}$ but rather "makes discretionary determinations about whether or not a detainee represents a continuing significant threat to the security of the United States." ${ }^{\prime 66}$ To accomplish this, the DoD developed a hearing process which would be repeated every three years, and a file review which could occur every six months.

In terms of the hearing, detainees are provided a military officer as personal representative to assist them with the review proceedings. That representative "shall be a military officer...other than a judge advocate..." 67 The detainee may have private counsel, but at no expense to the United States. The detainee is allowed to present written or oral statements at the hearing and call witnesses. The hearing is held before senior officials from the Departments of Defense, Homeland Security, Justice and State as well from the Chairman of the Joint Chiefs of Staff and the Director of National Intelligence. Their decision is essentially a recommendation to a Review Committee comprised of the Secretaries of State, Defense, Justice, and Homeland Security, the Director of National Intelligence, and the Chairman of the Joint Chiefs of Staff. Even then, "the Secretary of Defense shall be responsible for any decision to release or transfer an individual. The Secretary of Defense shall consider the Review Committee [and initial board] decisions in making a final decision, but shall not be bound by a Review Committee or [initial board] determination." 68

As of this writing, the United States has held only two periodic reviews. The first was not open to the public or the media, and the United States issued a press release in early 2014 announcing the review's completion. ${ }^{69}$ The first review concerned a Yemini national, Mahmud Al Mujahid, who was purportedly one of Osama Bin Laden's bodyguards. Pakisani forces captured Mujahid in late 2001 and transferred him to U.s. forces, who in turn transported him to

21 July 2013, available at: <http://www.miamiherald.com/2013/07/21/3512527/pentagonprepares-parole-board.html> (Accessed 15 July 2015).

65 Detainees at Guantanamo may challenge the legality of detention through petitioning for a writ of habeas corpus. While access to "the great writ" is of course significant, that access has yielded little for the detainees. See The Court Retreats on Habeas, New York Times, 13 June 2012, available at: <http://www.nytimes.com/2012/o6/14/opinion/the-supreme -court-retreats-on-habeas.html?_r=0 (Accessed 15 July 2015).

66 Directive-Type Memorandum (DTM) 12-005, supra note 64 at 8.

67 Id at 10.

68 Id at 18.

69 Department of Defense Press Release, Completion of First Guantanamo Periodic Review Board, 9 January 2014.

For use by the Author only | (C) 2016 Koninklijke Brill NV 
Guantanamo. The board concluded by consensus that Mujahid's "continued law of war detention is no longer necessary to protect against a continuing significant threat to the United States." ${ }^{.70}$ The board provided no insight into how - and when - Mujuahid ceased to pose a threat in 2014 versus at other early points in his 12 years of detention at Guantanamo.

The United States held the second review board in late January 2014. This board was open to the public and media, in a manner of speaking anyway. The United States issued a "fact sheet" on observer access ${ }^{71}$ as well as "observer ground rules"72 to which observes had to agree to follow. The observers were located in Virginia and watched a 19 minute delayed video feed of the proceedings, which involved the detainee and his attorney and personal representative at Guantanamo and the board members via video feed from Washington D.C. The detainee, Abdel Malik Ahmed Abdel Wahab al-Rahabi, was not provided an opportunity to speak. And the identities of the board members, or how they will determine if Rahibi poses a continuing threat to the United States, were also not disclosed. Commentators were not impressed, questioning whether the hearing was really "public" and wondering about the fate of detainees who, unlike Rahabi, may not have a lawyer. ${ }^{73}$ While those criticisms are valid, they reflect only a portion of what ails the current approach.

The proposed Guantanamo review process, while meeting LOAC standards for reviewing threat-based detention of civilians in some respects, falls short in important ways.

Taking as benchmarks the existing LOAC, discussed supra, an administrative board may serve as the detention review authority.However, the decision must be made not by one official. The Periodic Review Board creates the fiction of a board and a review committee, but neither is vested with authority to release,

70 Id. The board recommended Mujahid for transfer back to Yemen.

71 Periodic Review Secretariat, Fact Sheet: Observer Access to PRBS, 7 January 2014, available at: <http://www.prs.mil/Portals/6o/Documents/PressRelease/observeraccesstoprbs.pdf> (Accessed 15 July 2015).

72 Periodic Review Secretariat, Observer Ground Rules, 24 January 2014, available at: <http:// www.prs.mil/Portals/6o/Documents/PressRelease/ObserverGroundRulesJanuary242014. PDF > (Accessed 15 July 2015).

73 Daphne Eviatar, First "Public" PRB Hearing Raises More Questions Than it Answers, Just Security, 28 January 2014, available at: <https://www.justsecurity.org/6430/public -prb-hearing-raises-questions-answers/> (Accessed 15 July 2015).

For use by the Author only | (C) 2016 Koninklijke Brill NV 
only to make recommendations. As these recommendations are subject to review and reversal by the board's superiors, the process is not conducted with "absolute objectivity and impartiality" and lacks the "necessary guarantees of independence and impartiality" Geneva Convention IV requires. Given that ultimately a detainee may not be released unless the Secretary of Defense says so, and the Secretary is not bound by the board or review committee, the United States approach is really an elongated administrative decision made by one official. This the LOAC does not countenance.

The Guantanamo reviews will occur every three years, which falls well short of the LOAC security detention review standard of at least twice a year. Although the United States would conduct file reviews every six months, such reviews are inadequate. So, unlike the Afghanistan status determination which provided more than is required but too late, the Guantanamo periodic reviews afford too little too late.

It's by no means clear that there are any measures which the us could take at this point which would alter seemingly intractable negative perceptions of its detention policy and practice. But any effort to do so must more fully incorporate LOAC detention review principles and process. Doing so is required for at least two reasons. First, increased protections in reviewing detention are the tradeoff for adopting a lower, status based, threshold for detention in the first place. Second, detention can't realistically last for the duration of hostilities if there is no likelihood of those hostilities ending.

This proposal attempts to balance the needs of the State in confronting nonState actors against the practical difficulties posed by the lack of applicable law and asymmetric and amorphous nature of the attendant armed conflicts. It does not seek to create a "win" either for State armed forces or the competing demands by human rights groups. Aspects of the proposal will likely meet with both favor and disfavor. In short, the State would detain more non-state actors and by a lesser threshold. But in making detention more feasible, it is less likely that lethal force will need to be employed. Given the lesser detention threshold, the corresponding detention review process will need to be robust.

- The result is a proposed detention review process which includes:

- Detention based on status (membership) in organized arm groups;

- Automatic review hearings of the need for continued detention at least every 6 months;

- The rebuttable presumption at the hearing would be that continued detention is no longer required;

- An administrative board would conduct the hearing. A decision to release would be final; a decision for continued detention reviewable and potentially reversible by higher level government officials;

\section{For use by the Author only | (C) 2016 Koninklijke Brill NV}


- The detainee would have the right to appear at the hearing, to be assisted by counsel at no cost to them, and to present evidence including calling witnesses. ${ }^{74}$

\section{Conclusion}

The United States' efforts at detention of non-state actors over the last decade offer a host of lessons. Some of these are cautionary tales of what not to do. Others are effective and legitimate responses which needed earlier adoption. As problematic as aspects of that detention policy have been, the greater misfortune would be the international community ignoring those lessons learned. Detention of non-state actors is neither an exclusive U.S. issue nor one which is going away any time soon (if at all). Currently the series of armed conflicts in Syria or South Sudan and peacekeeping missions in the Central African Republic and the Democratic Republic of Congo pose looming questions concerning detention of non-state actors. And other conflicts and corresponding detention issues will follow.

Unless and until there is sufficient international consensus and momentum for either a new Geneva Convention or revising the current ones, policy decisions will need to fill the legal vacuum. Applying IAC rules to NIAC, and conflating status-based detention from Geneva Convention II I with conductbased detention review from Geneva Convention IV would provide more clarity and transparency and possibly even ever-elusive legitimacy.

\section{Bibliography}

Associated Press, US Military Gives Control of its Last Detention Center to Afghans, 25 March 2013, available at: <http://www.foxnews.com/politics/2013/o3/25/us -military-to-hand-over-detention-facility-to-afghan-government/> (Accessed 15 July 2015).

Borelli, S., Casting Light on the Legal Black Hole: International Law and Detentions Abroad in the "War on Terror" 87 International Review of the Red Cross 39 (2005). Bush, G.W., 'Memorandum for the Vice President and other National Security Advisors, Humane Treatment of Taliban and al Qaeda Detainees', 7 February 2002. Printed

74 This incorporates procedural rights from Geneva Convention IV applicable to those subject to criminal prosecution. See Geneva Convention IV Article 72.

For use by the Author only | (c) 2016 Koninklijke Brill NV 
in Karen Greenberg and Joshua Dratel (Eds.), The Torture Papers: The Road to Abu Ghraib (2005).

Clark, K., Terms of Internment, Foreign Policy, 1 June 2012, available at: <http:// foreignpolicy.com/2012/06/01/terms-of-internment/> (Accessed 15 July 2015).

Collis, H., \& Peterson, H., Head of al Qaeda in Pakistan Ayman al-Zawahri communicated with Nasser al-Wuhayshi, the head of al Qaeda in the Arabian Peninsula, Daily Mail, 4 August 2013.

Copenhagen Process; Principles and Guidelines (19 October 2012) available at: <http://um.dk/en/ /media/UM/English-site/Documents/Politics-and-diplomacy/ Copenhangen\%2oProcess\%2oPrinciples\%2oand\%20Guidelines.pdf> (Accessed 15 July 2015).

Corn, G., Thinking the Unthinkable: Has the Time Come to Offer Combatant Immunity to Non-State Actors? 22 Stanford Law and Politics Review 1 (2011).

Corn, G., Jensen, E., \& Watts, S., Understanding the Distinct Function of the Combatant Status Review Tribunals: A Response to Blocher, 116 Yale Law Journal Pocket Part $3^{27}$ (2007).

The Court Retreats on Habeas, NY Times, 13 June 2012, available at: <http://www .nytimes.com/2012/06/14/opinion/the-supreme-court-retreats-on-habeas.html? _r=0 $>$ (Accessed 15 July 2015).

Department of Defense Press Release, 'Completion of First Guantanamo Periodic Review Board', 9 January 2014.

Deputy Secretary for Defense, 'Directive-Type Memorandum (DTM) 12-005, Implementing Guidelines for Periodic Review of Detainees Held at Guantanamo Bay per Executive Order 13567', 9 May 2012, available at: <http://www.prs.mil/Portals/6o/ Documents/DTM-12-005_Implementing_Guidelines_for_Periodic_Review_of _Detainees_Held_at.pdf> (Accessed 15July 2015).

DeYoung, K., \& Warrick, J., Under Obama, More Targeted Killings Than Captures in Counterterrorism Efforts, Washington Post, 14 February 2010, available at: <http:// www.washingtonpost.com/wp-dyn/content/article/2010/02/13/AR2010021303748 .html> (Accessed 15 July 2015).

Department of Defense, 'Report on the Procedures for Unprivileged Enemy Belligerent Status Determinations', March 2012.

Eviatar, D., First "Public" PRB Hearing Raises More Questions Than it Answers, Just Security, 28 January 2014, available at: https://www.justsecurity.org/643o/publicprb-hearing-raises-questions-answers/ (Accessed 15 July 2015).

Goodman, R., The Second Annual Solf-Warren Lecture in International and Operational Law, 201 Milton Law Review 237 (2009).

ICRC, Commentary on the Geneva Convention III Relative to the Treatment of Prisoners of War (1960).

\section{For use by the Author only | (C) 2016 Koninklijke Brill NV}


Headquarters, United States Forces, Kabul, Afghanistan, Memorandum of Understanding between the Islamic Republic of Afghanistan and the United States of America on Transfer of U.S. Detention Facilities in Afghan Territory to Afghanistan, Kabul, 9 March 2012, <http://mfa.gov.af/en/news/7671> (Accessed 15 July 2015).

Memorandum for the President, 'Decision RE Application of the Geneva Convention on Prisoners of War to the Conflict with al Qaeda and the Taliban', 25 January 2002. Memorandum Opinion for the Counsel to the President, 'Status of Taliban Forces Under Article 4 of the Third Geneva Convention of 1949', 7 February 2002.

MSNBC, Letter to al-Zargai from al-Zawahri, nbcnews.com ni October 2005, available at: <http://www.nbcnews.com/id/9666242/ns/world_news-terrorism/t/letter-al -zarqawi-al-zawahri/\#.UhF9DGRoyAl> (Accessed 15 July 2015).

Obama, B., Executive Order 13567, 'Periodic Review of Individuals Detained at Guantanamo Bay Naval Station Pursuant to the Authorization for Use of Military Force', 10 March 2011, available at: <http://www.gpo.gov/fdsys/pkg/FR-2011-03-10/pdf/2011 -5728.pdf> (Accessed 15 July 2015).

Pakenham, T., The Boer War (1991).

Pejic, J., Procedural Principles and Safeguards for Internment/Administrative Detention in Armed Conflict and Other Situations of Violence, 87 International Review of the Red Cross 377 (2005).

Pejic, J., The Protective Scope of Common Article 3: More Than Meets the Eye, 93 International Review of the Red Cross 189 (2011).

Periodic Review Secretariat, 'Fact Sheet: Observer Access to PRBs', 17 January 2014, available at: <http://www.prs.mil/Portals/6o/Documents/PressRelease/observerac cesstoprbs.pdf> (Accessed 15 July 2015).

Periodic Review Secretariat, 'Observer Ground Rules', 24 January 2014, available at: <http://www.prs.mil/Portals/6o/Documents/PressRelease/ObserverGroundRules January242014.PDF> (Accessed 15 July 2015).

Rosenberg, C., Pentagon prepares review panels for 71 Guantánamo detainees, Miami Herald, 21 July 2013.

Sassòli, M., Bouvier, A., \& Quintin, A, How does Law Protect in War? Cases, Documents and Teaching Materials on Contemporary Practice in International Humanitarian Law (2011).

Sassóli, M., \& Olson,L., The RelationshipBetweenInternationalHumanitarianandHuman Rights Law Where it Matters: Admissible Killing and Internment of Fighters in NonInternational Armed Conflicts, 90 International Review of the Red Cross 599 (2008).

Sieff, K., In Afghanistan, a Second Guantanamo, Washington Post, 4 August 2013, available at: <http://www.washingtonpost.com/world/in-afghanistan-a-second-guantanamo/2013/08/04/e33e8658-f53e-11e2-81fa-8e83b3864c36_print.html> (Accessed 15 July 2015).

\section{For use by the Author only | (C) 2016 Koninklijke Brill NV}


Tuck, D., Detention by Armed Groups: Overcoming Challenges to Humanitarian Action, 93 International Review of the Red Cross 765 (2011).

U.S. Army Regulation 190-8, 'Enemy Prisoners of War, Retained Personnel, Civilian Internees and Other Detainees' (1997).

U.S. Army Field Manual, 'Counterinsurgency' December 2006.

U.S. Military Assistance Command, Vietnam, Directive No. 387-46, Military Intelligence: Combined Screening of Detainees, 27 December 1967 , reprinted in H. Levie, Documents on Prisoners of War 6o International Law Studies 748 (1979).

White House, 'Fact Sheet: New Actions on Guantanamo and Detainee Policy', 7 March 2011, available at: <http://www.whitehouse.gov/the-press-office/2011/03/07/factsheet-new-actions-guant-namo-and-detainee-policy> (Accessed 15July 2015).

\section{Treaties}

Geneva Convention (I) for the Amelioration of the Condition of the Wounded and Sick in Armed Forces in the Field, 1949, 75 UNTS 31.

Geneva Convention (II) for the Amelioration of the Condition of Wounded, Sick and Shipwrecked Members of Armed Forces at Sea 1949, 75 UNTS 85.

Geneva Convention (III) Relative to the Treatment of Prisoners of War 1949, 75 UNTS 135.

Geneva Convention (IV) Relative to the Protection of Civilian Persons in Time of War 1949, 75 UNTS 287.

Protocol I Additional to the Geneva Conventions of 12 August 1949, and relating to the Protection of Victims of International Armed Conflicts of 8 June 1977,1125 UNTS 3 .

Protocol II Additional to the Geneva Conventions of 12 August 1949, and relating to the Protection of Victims of Non-International Armed Conflicts of 8 June 1977, 1125 UNTS 6og.

\section{Cases}

Ex parte Quirin, 317 U.S. I (1942).

Hamdan v. Rumsfeld, 548 U.S. 557 (2006).

Hamdi v. Rumsfeld, 542 U.S. 507 (2004).

\section{For use by the Author only | (c) 2016 Koninklijke Brill NV}

